Article

\title{
Discovery of Flavonoids from Scutellaria baicalensis with Inhibitory Activity Against PCSK 9 Expression: Isolation, Synthesis and Their Biological Evaluation
}

\author{
Piseth Nhoek ${ }^{\dagger}$, Hee-Sung Chae ${ }^{\dagger}$, Jagadeesh Nagarajappa Masagalli, Karabasappa Mailar, \\ Pisey Pel, Young-Mi Kim, Won Jun Choi * and Young-Won Chin * \\ College of Pharmacy and Integrated Research Institute for Drug Development, Dongguk University-Seoul, \\ 32 Dongguk-lo, Ilsandong-gu, Goyang-si, Gyeonggi-do 10326, Korea; piseth2306@gmail.com (P.N.); \\ chaeheesung83@gmail.com (H.-S.C.); mnjagadeesh123@gmail.com (J.N.M.); Kitty_1506@yahoo.com (K.M.); \\ jully.christ07@gmail.com (P.P.); 0210121@hanmail.net (Y.-M.K.) \\ * Correspondence: mp89@dongguk.edu (W.J.C.); f2744@dongguk.edu (Y.-W.C.); Tel.: +82-31-961-5218 (Y.-W.C.) \\ + These authors contributed equally to this work.
}

Received: 23 January 2018; Accepted: 22 February 2018; Published: 24 February 2018

\begin{abstract}
Nine flavonoids were isolated and identified from a chloroform-soluble fraction of the roots of Scutellaria baicalensis through a bioactivity-guided fractionation using a proprotein convertase subtilisin/kexin type 9 (PCSK9) monitoring assay in HepG2 cells. All structures were established by interpreting the corresponding spectroscopic data and comparing measured values from those in the literature. All compounds were assessed for their ability to inhibit PCSK9 mRNA expression; compounds 1 (3,7,2'-trihydroxy-5-methoxy-flavanone) and 4 (skullcapflavone II) were found to suppress PCSK9 mRNA via SREBP-1. Furthermore, compound 1 was found to increase low-density lipoprotein receptor protein expression. Also, synthesis of compound $\mathbf{1}$ as a racemic mixture form (1a) was completed for the first time. Natural compound $\mathbf{1}$ and synthetic racemic $\mathbf{1 a}$ were evaluated for their inhibitory activities against PCSK9 mRNA expression and the results confirmed the stereochemistry of $\mathbf{1}$ was important.
\end{abstract}

Keywords: Scutellaria baicalensis; flavonoid; PCSK9; SREBP-1; low density lipoprotein receptor

\section{Introduction}

Cardiovascular disease (CVD) is a class of well-recorded diseases that lead to prominent adult mortality worldwide. High cholesterol level in the plasma has been identified as a major cause of CVD [1]. Cholesterol is an essential substance to cell membranes, but excess levels of it, either in biosynthesis, uptake, or storage, is tremendously associated to heart-related diseases. Over the past 20 years, statin therapy has been the standard treatment for successful cholesterol reduction [2]. However, some patients with familial hypercholesterolemia (FH) fail to reach the desired cholesterol concentration using common statin therapy $[3,4]$ even at maximal statin dose. Low density lipoprotein receptors (LDL-R) are expressed on the surface of hepatocytes and bind to LDL particles $[5,6]$. This LDL-R/LDL complex is primarily internalized into the cell through clathrin-coated vesicles, after which the complex dissociates and LDL-C gets degraded into lipids and amino acids. After this process, LDL-R moves back to the cell surface, suggesting that the recycling of LDL-R seems to be significant in lowering LDL-C levels in the plasma $[7,8]$. In patients with $\mathrm{FH}$, this recycling system is impaired by high concentrations of proprotein convertase subtilisin/kexin type 9 (PCSK9). PCSK9 is known to bind LDL-R and prevent its recycling, which decreases LDL-R expression on cell surfaces and consequently results in high levels of LDL-C in the plasma, leading to hypercholesterolemia $[9,10]$. Therefore, PCSK9 inhibition would increase LDL-R expression, which in turn decreases cholesterol 
levels in the plasma. Thus far, two antibody drugs have been approved as PCSK9 inhibitors, while no small molecules have ever reached at the clinical trials [11,12]. Moreover, only a few natural products in either extracts or individual chemicals have been explored for PCSK9 regulation [13-18].

Scutellaria baicalensis belongs to the Lamiaceae family [19] and is native to the soil of Asian countries. The plant has been used as a food additive and for traditional medicine [20]; its roots have been used for the treatment of allergies, inflammation [21,22], fever, dysentery [23], pneumonia, influenza [24], diarrhea [25], and have potential anticancer activities [26,27]. Phytochemical investigations of $S$. baicalensis roots have disclosed flavonoids, phenylethanoids and sterols as the main chemical constituents [28].

\section{Results and Discussion}

\subsection{Inhibitory Activity against PCSK9 mRNA Expression of Root Extract from S. baicalensis}

In the preliminary screening assay to assess medicinal plant extracts for their inhibitory activity against PCSK9 mRNA expression using HepG2 cells, a methanolic extract of $S$. baicalensis was found to inhibit PCSK9 mRNA expression. Thus, subsequent partitioning with organic solvents (hexane, chloroform, butyl alcohol and water-soluble extracts) was conducted and the resultant solvent-soluble extracts were tested again using the same bioassay (Figure 1). A chloroform-soluble extract demonstrated inhibitory activities on PCSK9 mRNA expression. Therefore, the chloroform-soluble fraction was further investigated to discover potential molecules in the extract that are responsible for the inhibitory effects on PCSK9 expression.

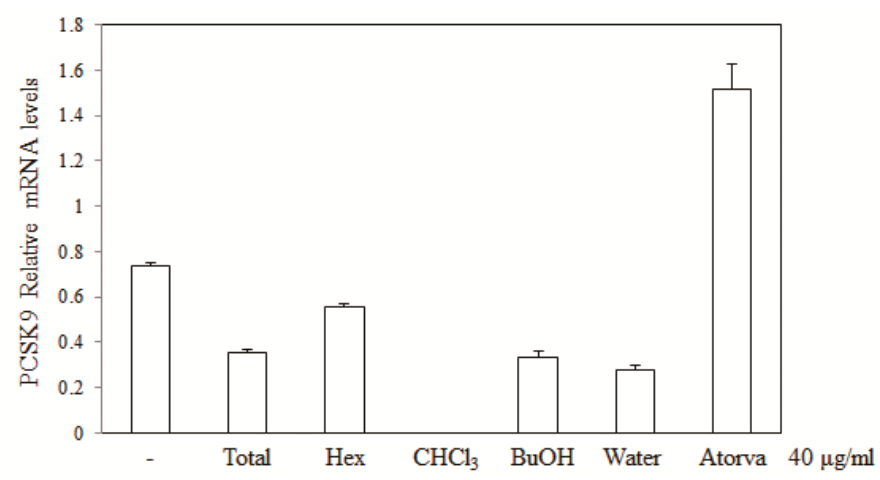

Figure 1. The effects of (total) methanol extracts, hexane (Hex), chloroform $\left(\mathrm{CHCl}_{3}\right)$, butyl alcohol $(\mathrm{BuOH})$ and aqueous fractions of $S$. baicalensis on PCSK9 mRNA expression in HepG2 cells. (Atorva $=$ Atorvastatin $)$.

\subsection{Identification of Isolates 1-9 from S. baicalensis}

In the present study, nine known structures were isolated (Figure 2), with structures confirmed by spectroscopic data analyses. The isolated compounds 1-9 were identified as follows: 3,7,2'-trihydroxy-5-methoxy-flavanone (1) [29], 3,5,7,2',6'-pentahydroxyflavanone (2) [30], 2-methyl-6-phenylpyran-4-one (3) [31,32], skullcapflavone II (4) [33], 5,7,2' ,6'-tetrahydroxyflavone (5) [30], 2,3-dihydro-7-hydroxy-2-(2-hydroxyphenyl)-5-methoxy-benzopyran-4-one (6) [34], 5,7,2'-trihydroxy-6'-methoxyflavone (7) [35], 5,7,2'-trihydroxyflavone (8) [36] and wogonin (9) [37,38], by extensive NMR experiments $\left({ }^{1} \mathrm{H},{ }^{13} \mathrm{C}, \mathrm{HSQC}\right.$, and $\left.\mathrm{HMBC}\right)$ and comparisons with values previously reported in the literature. Since there are no reports regarding full assignments for compound 3, all assignments were provided in the isolation method. 
<smiles>[R]c1cc(O)cc2c1C(=O)[C@H](O)[C@H](c1c([R])cccc1O)O2</smiles>

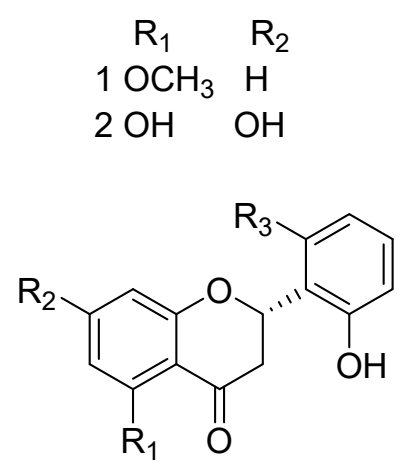<smiles>Cc1ccc(-c2cc(=O)cc(I)o2)cc1</smiles>

3<smiles>[R]c1cccc([R6])c1-c1cc(=O)c2c([R])c([R])c([R])c([R])c2o1</smiles>

$$
\begin{array}{clcc} 
& \mathrm{R}_{1} & \mathrm{R}_{2} & \mathrm{R}_{3} \\
5 & \mathrm{OH} & \mathrm{OH} & \mathrm{OH} \\
6 & \mathrm{OCH}_{3} & \mathrm{OH} & \mathrm{H}
\end{array}
$$

$\begin{array}{lllllll} & \mathrm{R}_{1} & \mathrm{R}_{2} & \mathrm{R}_{3} & \mathrm{R}_{4} & \mathrm{R}_{5} & \mathrm{R}_{6} \\ 4 & \mathrm{OH} & \mathrm{OCH}_{3} & \mathrm{OCH}_{3} & \mathrm{OCH}_{3} & \mathrm{OCH}_{3} & \mathrm{OH} \\ 7 & \mathrm{OH} & \mathrm{H} & \mathrm{OH} & \mathrm{H} & \mathrm{OCH}_{3} & \mathrm{OH} \\ 8 & \mathrm{OH} & \mathrm{H} & \mathrm{OH} & \mathrm{H} & \mathrm{H} & \mathrm{OH} \\ 9 & \mathrm{OH} & \mathrm{H} & \mathrm{OH} & \mathrm{OCH}_{3} & \mathrm{H} & \mathrm{H}\end{array}$

Figure 2. Chemical structures isolated from S. baicalensis.

\subsection{Stereochemistry Determination of Compound $\mathbf{1}$}

The stereochemistry of C-2 and C-3 in $\mathbf{1}$ was determined to be in a trans orientation based on the observation that the vicinal coupling constant between $\mathrm{H}-2$ and $\mathrm{H}-3$ was $11.2 \mathrm{~Hz}$, consistent with what is known in the literature regarding compound $2[39,40]$. Furthermore, circular dichroism (CD) spectroscopy of 1 revealed a positive Cotton effect at $328 \mathrm{~nm}$ and a negative Cotton effect at $299 \mathrm{~nm}$, suggesting that the configurations of C-2 and C-3 were $2 R$ and $3 R$, respectively [41]. The structure of 1 was thus characterized as $(2 R, 3 R), 3,7,2^{\prime}$-trihydroxy-5-methoxyflavanone.

\subsection{Inhibitory Activity against PCSK9 mRNA Expression of Isolates from S. baicalensis}

The isolated 1-6, 8 and 9 from this study were evaluated for their PCSK9 mRNA expression in HepG2 cells. Compound $\mathbf{7}$ was excluded for cytotoxicity (Figure 3A). Only $\mathbf{1}$ and $\mathbf{4}$ (skullcapflavone II) exhibited inhibitory activity at $20 \mu \mathrm{M}(84.4 \%$ and $42.4 \%$, respectively) (Figure 3B). In addition, some compounds from the same plant that have been previously isolated in our laboratory [26] were tested in the same assay at $20 \mu \mathrm{M}$ in order to assess structure-activity relationship (Supplementary Materials Figure S15). None of them were active in this assay system. From the structures 1 (active) and 6 (inactive), it was inferred that a hydroxyl group at C-3 position might provide the different activities. When the structure of skullcapflavone II (4) was compared with the similar structures of molsoflavone and alnetin in Supplementary Materials Figure S15, no conclusive result was reached due to the limited number of structures.

Out of the active compounds, compound 1 was further tested for its PCSK9 and LDL-R protein expression and it was found that compound 1 was able to inhibit PCSK9 and increase LDL-R protein expression, respectively (Figure 3C). As mentioned earlier, PCSK9 facilitates LDL-R degradation and prevents LDL-R recycling. Taking into consideration this function of PCSK9, compound 1 may potentially lower cholesterol levels by decreasing PCSK9 expression and concomitantly increasing LDL-R expression. 
A

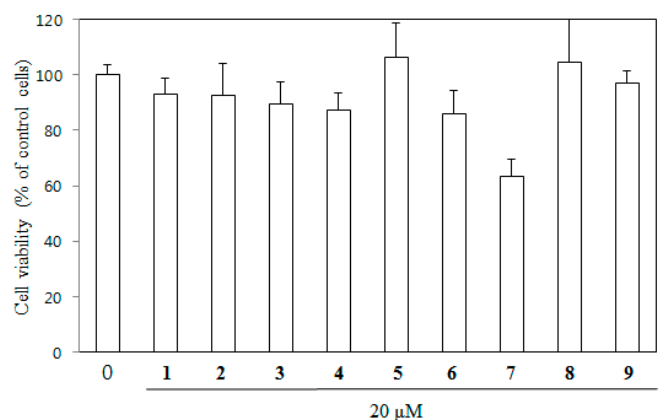

B

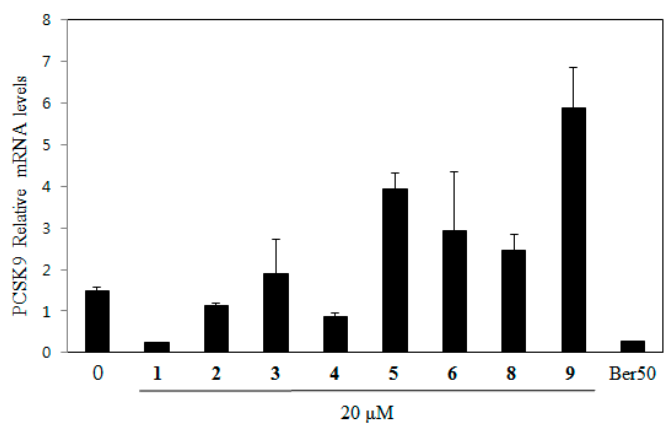

$\mathrm{C}$

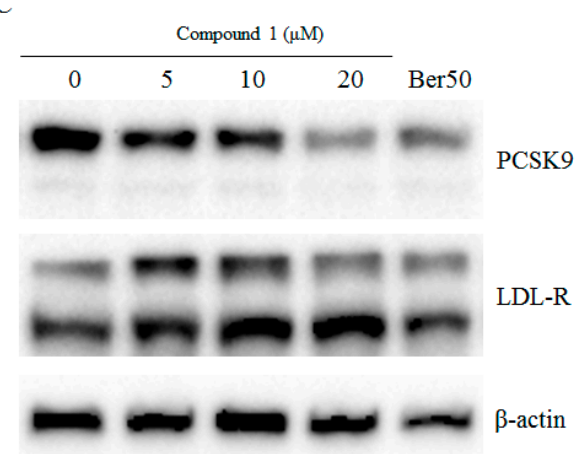

Figure 3. Effects of compounds from S. baicalensis on Cell viability, PCSK9 and LDL-R expression in HepG2 cells by MTT, qRT-PCR and western blot analysis. (A) Cells grown were treated with $20 \mu \mathrm{M}$ of compounds for $24 \mathrm{~h}$, and cell viability was assessed by the MTT assay; (B) Expression of PCSK9 was assayed by qRT-PCR in cells treated with compounds 1-9 except for 7, and berberine (50 $\mu \mathrm{M})$ for 24 h; (C) Expression of PCSK9 and LDL-R were assayed by western blots in cells treated with (1) and atorvastatin for $24 \mathrm{~h}$. (Ber50, berberine $50 \mu \mathrm{M}$ ).

\subsection{Comparison of Inhibitory Activity against PCSK9 mRNA Expression between Compound $\mathbf{1}$ and $\mathbf{1 a}$}

Due to its activity, we selected compound 1 for synthesis and designed the synthetic scheme shown in Scheme 1. Our approach to synthesize racemic 1a began with di-MOM protected 1-(2-hydroxy-4,6-bis(methoxymethyl)phenyl)ethanone (11), which was readily prepared from the commercially available $2^{\prime}, 4^{\prime}, 6^{\prime}$-trihydroxyacetophenone (10) by treatment with $\mathrm{MOMCl}$ and ethyldiisopropylamine [42]. Compound $\mathbf{1 1}$ was converted to chalcone $\mathbf{1 4}$ through methylation using dimethyl sulfate in acetone, followed by Claisen-Schmidt aldol condensation with 2-(methoxymethyl)benzaldehyde (13) in the presence of aqueous base [43,44]. Epoxidation of compound $\mathbf{1 4}$ with alkaline hydrogen peroxide at room temperature produced $\mathbf{1 5}$ in $89 \%$ yield [45]. Treatment of the epoxide $\mathbf{1 5}$ employing various acidic conditions for the purpose of instantaneous MOM deprotection and intramolecular 6-endo opening of epoxide afforded flavanol 1a, however, 
the yield of the product was limited to $3-5 \%$, with a variety of undesired products $[44,46]$. Finally, treatment of 15 with $12 \%$ conc $\mathrm{HCl}$ in methanol produced compound $1 \mathrm{a}$ as a racemic mixture in $11 \%$ yield as shown in Scheme 1 [47].<smiles>COc1cc(OC)c(C(C)=O)c(OC)c1</smiles><smiles>COc1cc(OC)c(C(=O)/C=C/c2c(OC)cccc2OC)c(OC)c1</smiles>
14

Reactions and conditions: a) MOMCl, DMF, DIPEA, DCM, 4 h. b) $\mathrm{K}_{2} \mathrm{CO}_{3},\left(\mathrm{CH}_{3}\right)_{2} \mathrm{SO}_{4},\left(\mathrm{CH}_{3}\right)_{2} \mathrm{CO}, 65^{\circ} \mathrm{C}, 2 \mathrm{~d}$. c) aldehyde 13, $30 \% \mathrm{KOH}$ (aq.), $\mathrm{EtOH}, 55^{\circ} \mathrm{C}, 6$ h. d) $\mathrm{K}_{2} \mathrm{CO}_{3}, \mathrm{H}_{2} \mathrm{O}_{2}$, $\mathrm{MeOH}, 1$ h. e) $12 \% \mathrm{HCl}$ in $\mathrm{MeOH}, \mathrm{MeOH}, 55^{\circ} \mathrm{C}, 30$ min. f) Isolated yields: compound 11 (71.4\%), 12 (99.0\%), 14 (85.8\%), and 15 (89.0\%).

Scheme 1. Synthesis of racemic compound 1a.

To compare bioactivity of natural 1 and racemic 1a, these two compounds were tested in HepG2 cells for their inhibitory activities against PCSK9 mRNA expression. As expected (Figure 4), natural 1 seemed to be more potent than racemic 1a because racemic 1a are composed of two isomers. From this result, PCSK9 mRNA expression might be modulated by 1 with specific configurations.
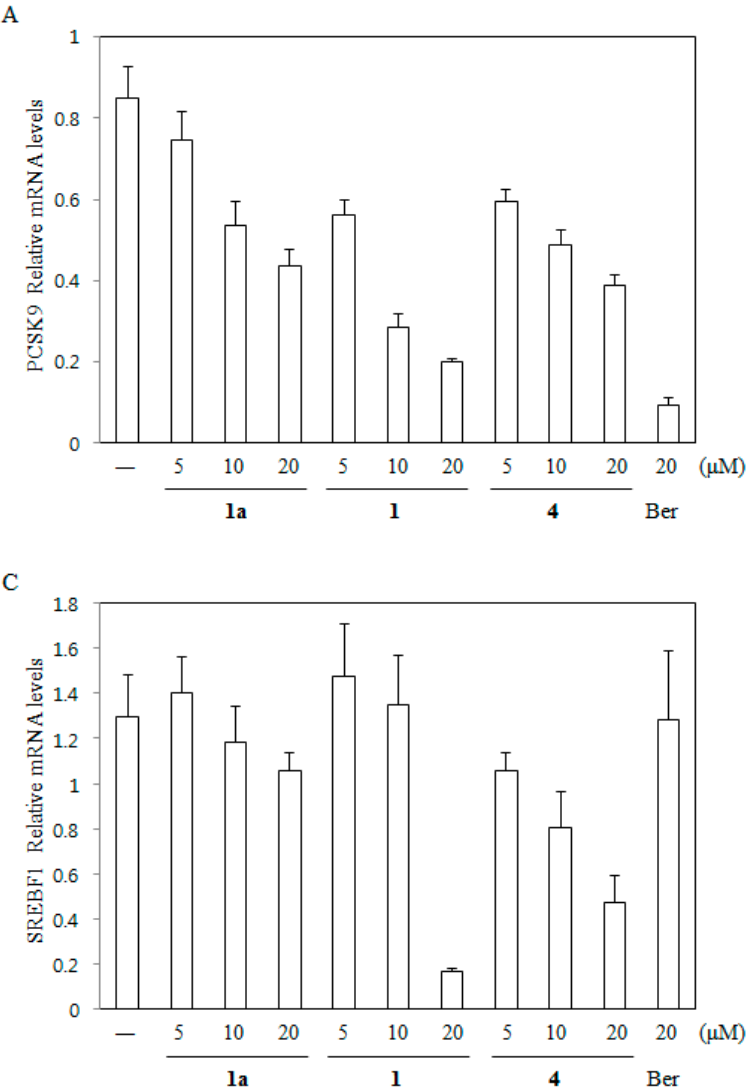

B

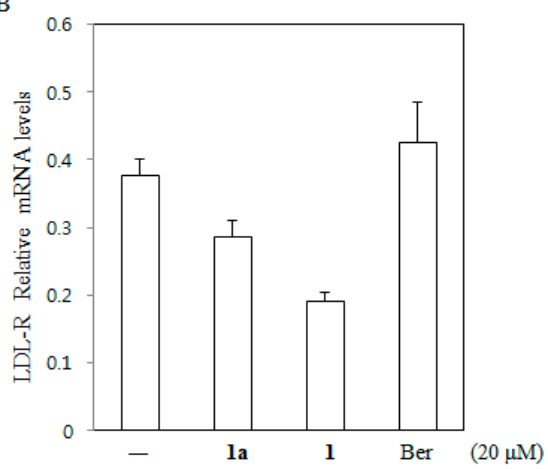

Figure 4. Expressions of PCSK9 (A) LDLR (B) and SREBF1 (C) were assayed by qRT-PCR in cells treated with compounds 1a, 1, 4 and Ber (berberine) at a indicated concentrations. 
Further analysis demonstrated that downregulation of SREBP-1 mRNA was detected in compounds 1 and 4, suggesting inhibition of PCSK9 mRNA expression was mediated by SREBP-1 as reported in the literature [48]. Thus, it merits enantioselective synthesis of $(2 R, 3 R)$ compound 1 and its derivatives for further chemical modifications and in vivo studies.

\section{Materials and Methods}

\subsection{General Information}

Nuclear magnetic resonance (NMR) spectra were obtained using a Varian 400 spectrometer (Varian, Palo Alto, CA, USA) $400 \mathrm{MHz}$ spectrometer operated at $400 \mathrm{MHz}$ for ${ }^{1} \mathrm{H}-\mathrm{NMR}$ and at $100 \mathrm{MHz}$ for ${ }^{13} \mathrm{C}-\mathrm{NMR}$. High-resolution mass spectra data were measured on a Xevo G2 Q-TOF mass spectrometer (Waters, Milford, MA, USA). Fourier Transform Infrared (FT-IR) recorded on a Nicolet ${ }^{\mathrm{TM}}$ iS $^{\mathrm{TM}} 5$ FT-IR spectrometer (ThermoFisher Scientific, Madison, WI, USA) were used. Ultraviolet visible spectroscopy was performed using a DU $730 \mathrm{UV} /$ Vis spectrophotometer (Beckman Coulter GmbH, North Rhine-Westphalia, Germany). Optical rotation and CD data are also given in the Supplementary file. Semi-preparative high performance liquid chromatography (HPLC) was performed on a system equipped with a Gilson 321 pump and Gilson 172 Diode Array Detector (Gilson, Madison, WI, USA) using YMC-pack Ph $(250 \times 20 \mathrm{~mm})$ and YMC-pack Ph $(250 \times 10 \mathrm{~mm})$ HPLC columns (YMC, Kyoto, Japan). Water was purified using a Milli-Q system (Waters Corporation, Milford, MA, USA). Column chromatography on C-18 RP silica gel (Cosmosil, Kyoto, Japan) and Sephadex LH-20 (GE Healthcare, Uppsala, Sweden) was conducted, and TLC analysis on silica gel 60 $\mathrm{F}_{254}$ plates (Merck, Darmstadt, Germany) was done. The spots were visualized by spraying with $10 \%$ aqueous $\mathrm{H}_{2} \mathrm{SO}_{4}$.

\subsection{Cell Culture and Chemical Reagents}

The HepG2 human hepatocellular liver cell line was obtained from the Korea Research Institute of Bioscience and Biotechnology (Daejeon, Korea) and grown in Eagle's Minimum Essential Medium (EMEM) containing $10 \%$ fetal bovine serum and $100 \mathrm{U} / \mathrm{mL}$ penicillin/streptomycin sulfate. Cells were incubated in a humidified $5 \% \mathrm{CO}_{2}$ atmosphere at $37^{\circ} \mathrm{C}$. EMEM, penicillin, and streptomycin were purchased from Hyclone (Logan, UT, USA). Bovine serum albumin was purchased from Sigma-Aldrich (St. Louis, MO, USA). Antibodies against PCSK9, LDL-R, and $\beta$-actin were purchased from Abcam, Inc. (Cambridge, MA, USA). PCSK9, LDL-R, SREBP1, and glyceraldehyde-3-phosphate dehydrogenase (GAPDH) oligonucleotide primers were purchased from Bioneer Corp. (Daejeon, Korea). The solvents for extraction and isolation (methanol, ethyl acetate, $n$-butyl alcohol, chloroform, $n$-hexane, etc.) were purchased from SK Chemical (Seoul, Korea). The solvents for HPLC-grade acetonitrile (MeCN) and methanol were also purchased from SK Chemical. The solvent for NMR $\left(\mathrm{CD}_{3} \mathrm{OD}\right)$ was obtained from Cambridge Isotope Laboratories, Inc. (Andover, MA, USA).

\subsection{Extraction, Isolation and Synthetic Method}

\subsubsection{Isolation Method}

The roots of $S$. baicalensis $(3 \mathrm{~kg})$ was extracted with $\mathrm{MeOH}$ three times $(18 \mathrm{~L} \times 3)$ at room temperature and evaporated in vacuo. The concentrated $\mathrm{MeOH}$ extract $(558.1 \mathrm{~g})$ was suspended in $\mathrm{H}_{2} \mathrm{O}$ and successively partitioned between hexane, chloroform, and butyl alcohol, to give the inactive residues of hexane-soluble fraction, butyl alcohol-soluble fraction, and water-soluble fraction, and the active residue of chloroform-soluble fraction $(34.7 \mathrm{~g})$. The chloroform-soluble fraction $(33.8 \mathrm{~g}$, SBC) was chromatographed over a silica gel column chromatography (CC) $(5 \times 90 \mathrm{~cm}, 685 \mathrm{~g})$ using a gradient of increasing polarity with chloroform: $\mathrm{MeOH}(200: 0-1: 1)$ as eluted solvents system and was fractioned into 50 sub-fractions (SBC1 50). SBC29 (8.8 g) was subjected to medium pressure liquid chromatography (MPLC), carried out with the binary system of $\mathrm{MeOH}-\mathrm{H}_{2} \mathrm{O}(0: 100,100: 0)$ 
to give 8 sub-fractions (SBC 29-1 8). SBC 29-6 was purified by size exclusion chromatography on Sephadex LH-20 CC by using chloroform:MeOH (1:1) as eluent, and washing by acetone to give 11 sub-fractions (SBC 29-6A K), including compound 4 (227.2 mg). SBC 29-7 was taken out $100 \mathrm{mg}$ to subject to semi-preparative high performance liquid chromatography (HPLC) performed on a $250 \times 21.2$ i.d.mm, Acclaim Polar Advantage 2, Thermo Scientific column (5 $\mu \mathrm{m}$, Life Technologies Korea LCC, Seoul, Korea), using MeCN: $\mathrm{H}_{2} \mathrm{O}$ (45:65) as solvent system, flow rate $3 \mathrm{~mL} / \mathrm{min}$ by isocratic elution method for $30 \mathrm{~min}$ and $\mathrm{MeCN} 100 \%$ for $5 \mathrm{~min}$ to afford compound 9 ( $t_{\mathrm{R}} 17.3 \mathrm{~min}, 1.3 \mathrm{mg}$ ). Sub-fraction SBC 44 and 45 were mixed together and separated on Sephadex LH-20 column with chloroform: $\mathrm{MeOH}(1: 1)$, to give 14 sub-fractions (SBC 44A N), includes compound 5 (10.3 mg). Sub-fraction SBC 44-J was subjected to HPLC separation $(250 \times 20$ i.d.mm, YMC-Pack Pro C18 RS, $5 \mu \mathrm{m}$ ), using MeCN: $\mathrm{H}_{2} \mathrm{O}$ as eluted solvent, flow rate $5 \mathrm{~mL} / \mathrm{min}$, by isocratic elution, using $\mathrm{MeCN} 30 \%$ for $25 \mathrm{~min}$, then increase directly to $\mathrm{MeCN} 35 \%$ and then maintained in the same isocratic mode for $15 \mathrm{~min}$ and $\mathrm{MeCN} 100 \%$ for $5 \mathrm{~min}$ to give compound $1\left(t_{\mathrm{R}} 23.2 \mathrm{~min}, 2.4 \mathrm{mg}\right)$. SBC 44-I was subjected to HPLC separation $(250 \times 21.2$ i.d.mm, Acclaim Polar Advantage 2, $5 \mu \mathrm{m})$ using $\mathrm{MeCN}: \mathrm{H}_{2} \mathrm{O}$, flow rate $3 \mathrm{~mL} / \mathrm{min}$, eluted with $\mathrm{MeCN} 30 \%$ for $25 \mathrm{~min}$, then MeCN 35\% for $15 \mathrm{~min}$ and MeCN 100\% for $5 \mathrm{~min}$ to give compound $6\left(t_{\mathrm{R}} 29.7 \mathrm{~min}, 1 \mathrm{mg}\right)$, compound $7\left(t_{\mathrm{R}} 41.7 \mathrm{~min}, 2.4 \mathrm{mg}\right.$ ) and compound 8 $\left(t_{\mathrm{R}} 43.8 \mathrm{~min}, 1 \mathrm{mg}\right)$. Sub-fraction SBC 42 was combined with sub-fraction SBC 41 and purified on Sephadex LH-20 CC to give 10 sub-fractions (SBC 42A J). Sub-fraction SBC 42-I was further purified by HPLC $(250 \times 21.2$ i.d.mm, Acclaim Polar Advantage $2,5 \mu \mathrm{m})$, with $\mathrm{MeCN}: \mathrm{H}_{2} \mathrm{O}(30: 70)$, flow rate $3 \mathrm{~mL} / \mathrm{min}$ by isocratic mode for $30 \mathrm{~min}$ and $\mathrm{MeCN} 100 \%$ for $5 \mathrm{~min}$ to afford compound $3\left(t_{\mathrm{R}} 22.5 \mathrm{~min}\right.$, $3.2 \mathrm{mg}$ ). Sub-fraction SBC 48 was mixed with sub-fraction SBC 46 and 47 and separated on Sephadex LH-20 CC by using chloroform: $\mathrm{MeOH}(1: 1)$ solvent system and washing by acetone $100 \%$ to afford 8 sub-fractions (SBC 48A H). Compound $2\left(t_{\mathrm{R}} 12.5 \mathrm{~min}, 1.6 \mathrm{mg}\right)$ was isolated from sub-fraction SBC48-G by HPLC separation $(250 \times 21.2$ i.d.mm, Acclaim Polar Advantage $2,5 \mu \mathrm{m})$ with $\mathrm{MeCN}: \mathrm{H}_{2} \mathrm{O}$ (25:75), flow rate $3 \mathrm{~mL} / \mathrm{min}$ by isocratic elution mode for $20 \mathrm{~min}$ and $\mathrm{MeCN} 100 \%$ for $5 \mathrm{~min}$.

2-Methyl-6-phenyl-4H-pyran-4-one (3): ${ }^{1} \mathrm{H}-\mathrm{NMR}\left(400 \mathrm{MHz}, \mathrm{CD}_{3} \mathrm{OD}\right) \delta: 6.30(1 \mathrm{H}, \mathrm{d}, J=2.0 \mathrm{~Hz}, \mathrm{H}-3), 6.82$ $(1 \mathrm{H}, d, J=2.0 \mathrm{~Hz}, \mathrm{H}-5), 7.55\left(3 \mathrm{H}, \mathrm{m}, \mathrm{H}-3^{\prime}, \mathrm{H}^{-} 4^{\prime}, \mathrm{H}-5^{\prime}\right), 7.90\left(2 \mathrm{H}, \mathrm{dd}, J=4.5,1.6 \mathrm{~Hz}, \mathrm{H}-2^{\prime}, \mathrm{H} 6^{\prime}\right), 2.43(3 \mathrm{H}$, s, H-7). ${ }^{13} \mathrm{C}-\mathrm{NMR}\left(100 \mathrm{MHz}, \mathrm{CD}_{3} \mathrm{OD}\right) \delta 169.2$ (C-2), 114.4 (C-3), 183.0 (C-4), 110.7 (C-5), 166.3 (C-6), 19.7 (C-7), $132.2\left(\mathrm{C}-1^{\prime}\right), 127.1\left(\mathrm{C}-2^{\prime}, \mathrm{C}-6^{\prime}\right), 130.2\left(\mathrm{C}-3^{\prime}, \mathrm{C}-4^{\prime}, \mathrm{C}-5^{\prime}\right)$.

\subsubsection{Synthesis Method}

Phloroacetophenoe monohydrate ( $>98 \%$ purity) and hydrogen peroxide ( $35 \%$ in water) were purchased from TCI Co., Ltd., (Tapei, Taiwan). Salicylaldehyde (97\%) was purchased from Junsei Chemicals Co., Ltd. (Chuo-ku, Tokyo, Japan). Methoxymethyl chloride ( $>95 \%)$ was purchased from Kanto Chemicals (Chuo-ku, Tokyo, Japan) with yield. Potassium carbonate (99.5\%) was purchased from Samchun Chemicals (Gangnam-gu, Seoul, South Korea). Terahydrofuran $(>99.9 \%)$ was purchased from Sigma-Aldrich (St. Louis, MO, USA). N-Ethyldiisopropylamine (99\%) was purchased from Alfa Aesar (Gangnam-gu, Seoul, South Korea).

1-(2-Hydroxy-4,6-bis(methoxymethyl)phenyl)ethanone (11). To a stirred solution of 1-(2,4,6-trihydroxyphenyl)ethanone (10, $1 \mathrm{~g}, 5.9 \mathrm{mmol})$ in $\mathrm{CH}_{2} \mathrm{Cl}_{2}(36 \mathrm{~mL})$, was added DMF $(1.2 \mathrm{~mL})$. The reaction mixture was cooled to $0{ }^{\circ} \mathrm{C}$, DIPEA $(3.1 \mathrm{~mL}, 17.7 \mathrm{mmol})$ was added and stirred for $5 \mathrm{~min}$. Chloro(methoxy)methane $(1 \mathrm{~g}, 12.4 \mathrm{mmol})$ in $\mathrm{CH}_{2} \mathrm{Cl}_{2}(5.8 \mathrm{~mL})$ was next added dropwise to the reaction mixture under a $\mathrm{N}_{2}$ atmosphere. The mixture was warmed to room temperature and stirred for $4 \mathrm{~h}$. The reaction mass was quenched with sat. aq. $\mathrm{NH}_{4} \mathrm{Cl}$, and the organic layer was separated. The aqueous layer was further extracted with $\mathrm{CH}_{2} \mathrm{Cl}_{2}(2 \times 50 \mathrm{~mL})$, the combined organic layer was washed with brine solution and dried over $\mathrm{MgSO}_{4}$, filtered, and evaporated under vacuum. The residue was purified by column chromatography (petroleum ether/ethyl acetate, 8:2, $v / v$ ) to afford compound 11 as a colorless oil $(0.95 \mathrm{~g}, 71.4 \%) .{ }^{1} \mathrm{H}-\mathrm{NMR}\left(\mathrm{CDCl}_{3}\right) \delta 13.74(\mathrm{~s}, 1 \mathrm{H}), 6.26(\mathrm{~s}, 1 \mathrm{H})$, 
$6.24(\mathrm{~s}, 1 \mathrm{H}), 5.26(\mathrm{~s}, 2 \mathrm{H}), 5.17(\mathrm{~s}, 2 \mathrm{H}), 3.52(\mathrm{~s}, 3 \mathrm{H}), 3.47(\mathrm{~s}, 3 \mathrm{H}), 2.66(\mathrm{~s}, 3 \mathrm{H}) .{ }^{13} \mathrm{C}-\mathrm{NMR}\left(\mathrm{CDCl}_{3}\right) \delta 203.2$, $166.8,163.5,160.4,106.9,97.1,94.5,94.0,56.7,56.5,33.0$.

1-(2-Methoxy-4,6-bis(methoxymethyl)phenyl)ethanone (12). To a stirred solution of compound 11 (0.95 g, $3.7 \mathrm{mmol})$ in acetone $(20 \mathrm{~mL}), \mathrm{K}_{2} \mathrm{CO}_{3}(1.5 \mathrm{~g}, 11.1 \mathrm{mmol})$ and $\left(\mathrm{CH}_{3}\right)_{2} \mathrm{SO}_{4}(2 \times 0.26 \mathrm{~mL}, 5.5 \mathrm{mmol})$ were added at $15 \mathrm{~min}$ intervals at room temperature. The reaction mixture was heated to reflux and maintained for $2 \mathrm{~d}$. The reaction mass was cooled to room temperature, filtered and the filtrate was evaporated to dryness. The crude product was purified by column chromatography (petroleum ether/ethyl acetate, 8:2,v/v) to afford compound 12 as a pale brown oil $(1 \mathrm{~g}, 99.0 \%) .{ }^{1} \mathrm{H}-\mathrm{NMR}\left(\mathrm{CDCl}_{3}\right)$ $\delta 6.45(d, J=2.0 \mathrm{~Hz}, 1 \mathrm{H}), 6.31(d, J=2.0 \mathrm{~Hz}, 1 \mathrm{H}), 5.16(\mathrm{~s}, 2 \mathrm{H}), 5.14(\mathrm{~s}, 2 \mathrm{H}), 3.78(\mathrm{~s}, 3 \mathrm{H}), 3.48(\mathrm{~s}, 3 \mathrm{H}), 3.46$ $(\mathrm{s}, 3 \mathrm{H}), 2.48(\mathrm{~s}, 3 \mathrm{H}) .{ }^{13} \mathrm{C}-\mathrm{NMR}\left(\mathrm{CDCl}_{3}\right) \delta 201.8,159.7,157.9,155.4,115.8,95.8,94.8,94.4,93.8,56.3,56.2$, $55.8,32.5$.

(E)-1-(2-Methoxy-4,6-bis(methoxymethyl)phenyl)-3-(2-(methoxymethyl)phenyl)prop-2-en-1-one (14). To a stirred solution of compound $12(0.45 \mathrm{~g}, 1.66 \mathrm{mmol})$ in ethanol $(10 \mathrm{~mL})$ at $0{ }^{\circ} \mathrm{C}$, was added aq. $\mathrm{KOH}$ (4.5 mL, 30\% solution) dropwise. After stirring for $10 \mathrm{~min}$ then 2-(methoxymethyl) benzaldehyde $(13,0.415 \mathrm{~g}, 2.49 \mathrm{mmol})$ was added in one portion. The reaction mass was heated to $55^{\circ} \mathrm{C}$ and maintained for $6 \mathrm{~h}$. The reaction progress was monitored by TLC. The reaction mass was cooled to $0{ }^{\circ} \mathrm{C}$, acidified to $\mathrm{pH} 5-6$ using $2 \mathrm{~N} \mathrm{HCl}$, and extracted with $\mathrm{CH}_{2} \mathrm{Cl}_{2}(3 \times 25 \mathrm{~mL})$. The combined organic layer was washed with brine solution, dried over $\mathrm{MgSO}_{4}$, filtered and evaporated under vacuum. The crude product was purified by column chromatography (petroleum ether/ethyl acetate, 7:3, $v / v$ ) to afford compound 14 as a low melting solid $(0.6 \mathrm{~g}, 85.8 \%)$. ${ }^{1} \mathrm{H}-\mathrm{NMR}\left(\mathrm{CDCl}_{3}\right) \delta 7.75(d, J=16 \mathrm{~Hz}, 1 \mathrm{H})$, $7.56(d, J=7.6,1.2 \mathrm{~Hz}, 1 \mathrm{H}), 7.31(\mathrm{t}, J=8.8,1.6, \mathrm{~Hz}, 1 \mathrm{H}), 7.12(d, J=8.0 \mathrm{~Hz}, 1 \mathrm{H}), 7.04(d, J=16.4 \mathrm{~Hz}, 1 \mathrm{H})$, $7.00(\mathrm{t}, J=7.6 \mathrm{~Hz}, 1 \mathrm{H}), 6.51(d, J=2.0 \mathrm{~Hz}, 1 \mathrm{H}), 6.36(d, J=2.0 \mathrm{~Hz}, 1 \mathrm{H}), 5.20(\mathrm{~s}, 2 \mathrm{H}), 5.19(\mathrm{~s}, 2 \mathrm{H}), 5.11$ $(\mathrm{s}, 2 \mathrm{H}), 3.76(\mathrm{~s}, 3 \mathrm{H}), 3.50(\mathrm{~s}, 3 \mathrm{H}), 3.44(\mathrm{~s}, 3 \mathrm{H}), 3.40(\mathrm{~s}, 3 \mathrm{H}) .{ }^{13} \mathrm{C}-\mathrm{NMR}\left(\mathrm{CDCl}_{3}\right) \delta 194.6,159.8,158.5,156,2$, $156.0,139.8,131.5,129.5,128.6,124.7,122.0,115.0,114.0,95.9,94.7,94.6,94.5,94.0,56.2,55.9$.

(2-Methoxy-4,6-bis(methoxymethyl)phenyl)(3-(2-(methoxymethyl)phenyl)oxiran-2-yl)methanone (15). To a stirred solution of compound $14(0.07 \mathrm{~g}, 0.18 \mathrm{mmol})$ in methanol $(6 \mathrm{~mL})$, was added $\mathrm{K}_{2} \mathrm{CO}_{3}(0.069 \mathrm{~g}$, $0.5 \mathrm{mmol})$ followed by dropwise addition of $\mathrm{H}_{2} \mathrm{O}_{2}(0.13 \mathrm{~mL}, 1.3 \mathrm{mmol}, 35 \%$ aq. solution) at room temperature. The reaction mass was stirred for $1 \mathrm{~h}$. After completion of starting material, mixture was diluted with ether and washed twice with saturated aq. $\mathrm{NH}_{4} \mathrm{Cl}$ solution. The combined organic layer was dried over $\mathrm{MgSO}_{4}$, filtered and evaporated under vacuum. The crude product was purified by column chromatography (petroleum ether/ethyl acetate, 7:3,v/v) to afford compound 15 as a light green oil $(0.065 \mathrm{~g}, 89.0 \%) .{ }^{1} \mathrm{H}-\mathrm{NMR}\left(\mathrm{CDCl}_{3}\right) \delta 7.25(\mathrm{~m}, 2 \mathrm{H}), 7.19(d, J=8.0,2.0, \mathrm{~Hz}, 1 \mathrm{H}), 7.09$ $(d, J=8.0 \mathrm{~Hz}, 1 \mathrm{H}), 6.99(\mathrm{t}, J=8.0 \mathrm{~Hz}, 1 \mathrm{H}), 6.45(d, J=2.0 \mathrm{~Hz}, 1 \mathrm{H}), 6.31(d, J=2.0 \mathrm{~Hz}, 1 \mathrm{H}), 7.39$ $(d, J=2.0 \mathrm{~Hz}, 1 \mathrm{H}), 3.87(d, J=2.0 \mathrm{~Hz}, 1 \mathrm{H}), 3.77(\mathrm{~s}, 3 \mathrm{H}), 3.47(\mathrm{~s}, 3 \mathrm{H}), 3.45(\mathrm{~s}, 3 \mathrm{H}), 3.38(\mathrm{~s}, 3 \mathrm{H}),{ }^{13} \mathrm{C}-\mathrm{NMR}$ $\left(\mathrm{CDCl}_{3}\right) \delta 196.8,161.0,159.4,157.1,155.9,129.4,125.4,125.3,122.0,114.1,111.7,95.7,94.8,94.6,94.3$, 93.7, 63.7, 56.3, 56.3, 56.2, 55.9, 55.0.

2,3-Dihydro-3,7-dihydroxy-2-(2-hydroxyphenyl)-5-methoxychromen-4-one (1a). To a stirred solution of compound $15(0.05 \mathrm{~g}, 0.11 \mathrm{mmol})$ in $\mathrm{MeOH}(2 \mathrm{~mL})$, was added $\mathrm{HCl}$ in methanol $(0.2 \mathrm{~mL}, 12 \% \mathrm{Wt})$ at room temperature. The reaction mass was heated to $55^{\circ} \mathrm{C}$ and stirred for $30 \mathrm{~min}$. After cooling, the reaction mixture was concentrated in vacuo, the crude product was then purified by prep. TLC (silica gel, $\left.\mathrm{CH}_{2} \mathrm{Cl}_{2} / \mathrm{MeOH}, 9.5: 0.5, v / v\right)$ to yield $1 \mathrm{a}\left(4 \mathrm{mg}, 11.7 \%\right.$ ) as a white solid of m.p. $124-126^{\circ} \mathrm{C}$. ${ }^{1} \mathrm{H}-\mathrm{NMR}\left(\mathrm{CD}_{3} \mathrm{OD}\right) \delta 7.41(1 \mathrm{H}, d d, J=7.6,1.5 \mathrm{~Hz}), 7.17(1 \mathrm{H}, \mathrm{td}, J=7.6,1.5 \mathrm{~Hz}), 6.82(1 \mathrm{H}, d, J=8.5 \mathrm{~Hz})$, $6.88(1 \mathrm{H}, d, J=7.6 \mathrm{~Hz}), 6.09(d, J=2.0 \mathrm{~Hz}, 1 \mathrm{H}), 5.97(d, J=2.0 \mathrm{~Hz}, 1 \mathrm{H}), 5.48(1 \mathrm{H}, d, J=11.2 \mathrm{~Hz}), 4.61(1 \mathrm{H}$, $d, J=11.2 \mathrm{~Hz}), 3.83(3 \mathrm{H}, \mathrm{s}) .{ }^{13} \mathrm{C}-\mathrm{NMR}\left(\mathrm{CD}_{3} \mathrm{OD}\right) \delta 192.2,166.6,165.7,164.0,156.4,130.3,128.8,123.6$, $119.8,115.9,102.9,96.2,93.5,78.3,72.7,55.5$. HRESIMS m/z $[\mathrm{M}+\mathrm{H}]^{+} 303.0869$ (calcd for $\mathrm{C}_{16} \mathrm{H}_{14} \mathrm{O}_{6}$ 303.0869).

Supplementary Materials: Supplementary materials are available online. 
Acknowledgments: This study was supported by the National Research Foundation of Korea (NRF) grant funded by the Korea government (MSIT) (NRF-2015R1A2A2A01006736, Y.-W. Chin).

Author Contributions: Y.-W. Chin and W. J. Choi conceived and designed the experiments; P. Nhoek, J. N. Masagalli, K. Mailar, H.-S. Chae, P. Pel, and Y.-M. Kim performed the experiments; Y.-W. Chin and W. J. Choi analyzed the data; Y.-W. Chin and W. J. Choi contributed reagents/materials/analysis tools; Y.-W. Chin and W. J. Choi wrote the paper.

Conflicts of Interest: The authors declare no conflict of interest.

\section{References}

1. He, X.-X.; Zhang, R.; Zou, P.-Y.; Liu, Y.W.; Zha, X.-N.; Shan, S.-S.; Liu, C.-Y. The efficacy advantage of evolocumab (AMG 145) dosed at $140 \mathrm{mg}$ every 2 weeks versus $420 \mathrm{mg}$ every 4 weeks in patients with hypercholesterolemia: Evidence from a meta-analysis. Eur. J. Intern. Med. 2017, 38, 52-60. [CrossRef] [PubMed]

2. Puri, R.; Nissen, S.E.; Somaratne, R.; Cho, L.; Kastelein, J.J.P.; Ballantyne, C.M.; Koenig, W.; Anderson, T.J.; Yang, J.; Kassahun, H.; et al. Impact of PCSK9 inhibition on coronary atheroma progession: Rationale and design of global assessment of plaque regression with a PCSK9 antibody as measured by intravascular ultrasound (GLAGOV). Am. Heart J. 2016, 176, 83-92. [CrossRef] [PubMed]

3. Bos, S.; Duvekot, M.H.C.; Kate, G.-J.R.T.; Verhoeven, A.J.M.; Mulder, M.T.; Schinkel, A.F.L.; Nieman, K.; Watts, G.F.; Sijbrands, E.J.G.; Lennep, J.E.R.V. Carotid artery plaques and intima medial thickness in familial hypercholesteraemic patients on long-term statin therapy: A case control study. Atherosclerosis 2017, 256, 62-66. [CrossRef] [PubMed]

4. Versmissen, J.; Oosterveer, D.M.; Yazdanpanah, M.; Defesche, J.C.; Basart, D.C.G.; Liem, A.H.; Heeringa, J.; Witteman, J.C.; Lansberg, P.J.; Kastelein, J.J.P.; et al. Efficay of statins in familial hypercholesterolaemia: A long term cohort study. BMJ 2008, 337, a2423. [CrossRef] [PubMed]

5. Steinberg, D.; Witztum, J.L. Inhibition of PCSK9: A powerful weapon for achieving ideal LDL cholesterol levels. Proc. Natl. Acad. Sci. USA 2009, 106, 9546-9547. [CrossRef] [PubMed]

6. Page, M.M.; Watts, G.F. PCSK9 inhibitors-mechanisms of action. Aust. Prescr. 2016, 39, 164-167. [CrossRef] [PubMed]

7. Lagor, W.R.; Millar, J.S. Overview of the LDL receptor: Relevance to cholesterol metabolism and future approaches for the treatment of coronary heart disease. J. Recept. Ligand Channel Res. 2010, 3, 1-14. [CrossRef]

8. Li, J.; Tumanut, C.; Gavigan, J.-A.; Huang, W.-J.; Hampton, E.N.; Tumanut, R.; Suen, K.F.; Trauger, J.W.; Spraggon, G.; Lesley, S.A.; et al. Secreted PCSK9 promotes LDL receptor degradation independently of proteolytic activity. Biochem. J. 2007, 406, 203-207. [CrossRef] [PubMed]

9. Lagace, T.A.; Curtis, D.E.; Garuti, R.; McNutt, M.C.; Park, S.W.; Prather, H.B.; Anderson, N.N.; Ho, Y.K.; Hammer, R.E.; Horton, J.D. Secreted PCSK9 decreases the number of LDL receptors in hepatocytes and in livers of parabiotic mice. J. Clin. Investig. 2006, 116, 2995-3005. [CrossRef] [PubMed]

10. Abifadel, M.; Elbitar, S.; Khoury, P.E.; Ghaleb, Y.; Chémaly, M.; Moussalli, M.L.; Rabés, J.P.; Varret, M.; Boileau, C. Living the PCSK9 adventure: From the identification of a new gene in familial hypercholesterolemia towards a potential new class of anticholesterol drugs. Curr. Atheroscler. Rep. 2014, 16, 439. [CrossRef] [PubMed]

11. Yadav, K.; Sharma, M.; Ferdinand, K.C. Proprotein convertase subtilisin/kexin type 9 (PCSK9) inhibitors: Present prerspective and future horizons. Nutr. Metab. Cardiovasc. Dis. 2016, 26, 853-862. [CrossRef] [PubMed]

12. Ramanathan, A.; Gusarova, V.; Stahl, N.; Gurnett-Bander, A.; Kyratsous, C.A. Aliromab, a therapeutic human antibody to PCSK9, does not affect CD81 levels or hepatitis C virus entry and replication into hepatocytes. PLoS ONE 2016. [CrossRef] [PubMed]

13. Dong, B.; Li, H.; Signh, A.B.; Cao, A.; Liu, J. Inhibition of PCSK9 transcription by berberine involves down-regulation of hepatic HNF1 $\alpha$ protein expression through the ubiquitin-proteasome degradation pathway. J. Biol. Chem. 2015, 290, 4047-4058. [CrossRef] [PubMed]

14. Miranda, C.L.; Elias, V.D.; Hay, J.J.; Choi, J.; Reed, R.L. Xanthohumol improves dysfuctional glucose and lipid metabolism in diet-induced obese C57BL/6J mice. Arch. Biochem. Biophys. 2016, 599, 22-30. [CrossRef] [PubMed] 
15. Pel, P.; Chae, H.-S.; Nhoek, P.; Yeo, W.; Kim, Y.-M.; Chin, Y.-W. Lignans from the fruits of Schisandra chinensis (Turcz.) Baill inhibit proprotein convertase subtilisin/kexin type 9 expression. Phytochemistry 2017, 136, 119-124. [CrossRef] [PubMed]

16. Wang, Y.; Ye, J.; Li, J.; Chen, C.; Huang, J.; Liu, P.; Huang, H. Polydatin ameliorates lipid and glucose metabolism in type 2 diabetes mellitus by downregulating proprotein convertase subtilisin/kexin type 9 (PCSK9). Cardiovasc. Diabetol. 2016, 15, 19. [CrossRef] [PubMed]

17. Taechalertpaisarn, J.; Zhao, B.; Liang, X.; Burgess, K. Small molecule inhibitors of the PCSK9-LDLR interaction. J. Am. Chem. Soc. 2018, in press. [CrossRef] [PubMed]

18. Bang, S.; Chae, H.-S.; Lee, C.; Choi, H.G.; Ryu, J.; Li, W.; Lee, H.; Jeong, G.-S.; Chin, Y.-W.; Shim, S.H. New aromatic compounds from the fruiting body of Sparassis crispa (Wulf.) and their inhibitory activities on proprotein convertase subtilisin/kexin type 9 mRNA expression. J. Agric. Food Chem. 2017, 65, 6152-6157. [CrossRef] [PubMed]

19. Takahashi, H.; Chen, M.C.; Pham, H.; Angst, E.; King, J.C.; Park, J.; Brovman, E.Y.; Ishiguro, H.; Harris, D.M.; Reber, H.A.; et al. Baicalein, a component of Scutellaria baicalensis, induces apoptosis by Mcl-1 down-regulation in human pancreatic cancer cells. Biochim. Biophys. Acta 2011, 1813, 1465-1474. [CrossRef] [PubMed]

20. Lu, Y.; Joerger, R.; Wu, C. Study of the chemical composition and antimicrobial activities of ethanolic extracts from roots of Scutellaria baicalensis Georgi. J. Agric. Food Chem. 2011, 59, 10934-10942. [CrossRef] [PubMed]

21. Huang, W.-H.; Lee, A.-R.; Yang, C.-H. Antioxidative and anti-Inflammatory activities of polyhydroxyflavonoids of Scutellaria baicalensis Georgi. Biosci. Biotechnol. Biochem. 2006, 70, 2370-2380. [CrossRef] [PubMed]

22. Gao, Z.; Huang, K.; Yang, X.; Xu, H. Free radical scavenging and antioxidant activities of flavonoids extracted from the radix of Scutellaria baicalensis Georgi. Biochim. Biophys. Acta 1999, 1472, 643-650. [CrossRef]

23. Kim, H.-M.; Moon, E.-J.; Li, E.; Kim, K.-M.; Nam, S.-Y.; Chung, C.-K. The nitric oxide-producing activities of Suctellaria baicalensis. Toxicology 1999, 135, 109-115. [CrossRef]

24. Ji, S.; Wang, Q.; Miao, W.-J.; Li, Z.-W.; Si, L.-L.; Qiao, X.; Yu, S.-W.; Zhou, D.-M.; Ye, M. Anti-H1N1 virus, cytotoxic and Nrf2 activation activities of chemical constituents from Scutellaria baicalensis. J. Ethnopharmacol. 2015, 176, 475-484. [CrossRef] [PubMed]

25. Hirotani, M.; Kuroda, R.; Suzuki, H.; Yoshikawa, T. Cloning and expression of UDP-glucose flavonoid 7-O-glucosyltransferase from hairy root cultures of Scutellaria baicalensis. Planta 2000, 210, 1006-1013. [CrossRef] [PubMed]

26. Zhang, D.Y.; Wu, J.; Ye, W.; Xue, L.; Jiang, S.; Yi, J.; Zhang, W.; Wei, H.; Sung, M.; Wang, W.; et al. Inhibition of cancer cell proliferation and prostaglandin E2 synthesis by Scutellaria baicalensis. Cancer Res. 2003, 63, 4037-4043. [PubMed]

27. Choi, Y.O.; Song, H.-H.; Kim, Y.-M.; Kang, N.S.; Han, S.-Y.; Chin, Y.-W. c-Met and ALK inhibitory constituents from Scutellaria baicalensis. Bull. Korean Chem. Soc. 2015, 36, 402-405. [CrossRef]

28. Tuan, P.A.; Kim, J.K.; Lee, S.; Chae, S.C.; Park, S.U. Molecular characterization of carotenoid cleavage dioxygenases and the effect of gibberellin, abscisic acid, and sodium chloride on the expression of genes involved in the carotenoid biosynthetic pathway and carotenoid accumulation in the callus of Scutellaria baicalensis Georgi. J. Agric. Food Chem. 2013, 61, 5565-5572. [CrossRef] [PubMed]

29. Wang, J.; Zhao, B.; Xu, H.; Zhao, M.; Tang, W.; Zhang, S. Study on chemical constituent of Scutellaria regeliana. China J. Chin. Mater. Med. 2011, 36, 3270-3275. [CrossRef]

30. Kimura, Y.; Sumiyoshi, M. Effects of various flavononoids isolated from Scutellaria baicalensis roots on skin damage in acute UVB-irradiated hairless mice. J. Pharm. Pharmacol. 2011, 63, 1613-1623. [CrossRef] [PubMed]

31. Yan, R.-Y.; Cao, Y.-Y.; Chen, C.-Y.; Dai, H.-Q.; Yu, S.-X.; Wei, J.-J.; Li, H.; Yang, B. Antioxidant flavonoids from the seed of Oroxylum indicum. Fitoterapia 2011, 8, 841-848. [CrossRef] [PubMed]

32. Kishida, Y.; Hiraoka, T.; Yoshimoto, M. Studies on acetylenic compounds. XLIX. reactions of linearconjugated diynones. Chem. Pharm. Bull. 1969, 17, 2126-2134. [CrossRef]

33. Iinuma, M.; Matsuura, S. Synthetic studies of the flavone derivatives. VI. The synthesis of skullcapflavone I, II and related flavones. Yakugaku Zasshi 1979, 99, 657-662. [CrossRef] [PubMed] 
34. Miyaichi, Y.; Hanamitsu, E.; Kizu, H.; Tomimori, T. Studies on the constituents of Scutellaria species (XXII). Constituents of the roots of Scutellaria amabilis Hara. Chem. Pharm. Bull. 2006, 54, 435-441. [CrossRef] [PubMed]

35. Tanaka, T.; Iinuma, M.; Mizuno, M. Synthesis of flavonoids in Scutellaria spp. II. synthesis of 2',6'-dioxygenated flavones. Yakugaku Zasshi 1987, 107, 827-829. [CrossRef]

36. Park, Y.; Moon, B.-H.; Lee, E.; Lee, Y.; Yoon, Y.; Ahn, J.-H.; Lim, Y. ${ }^{1} \mathrm{H}$ and ${ }^{13} \mathrm{C}-\mathrm{NMR}$ data of hydroxyflavone derivatives. Magn. Reson. Chem. 2007, 45, 674-679. [CrossRef] [PubMed]

37. Delange, D.M.; Rico, C.L.M.; Canavaciolo, V.G.; Cuellar, A.C.; Oliver, E.S. Selective and high yield isolation of pure wogonin from the aerial parts of Scutellaria havanesis Jacq. Int. J. Pharm. Sci. Rev. Res. 2015, 30, 104-108.

38. Isobe, T.; Ohsaki, A.; Nagata, k. Antibacterial constituents against Helicobacter pylori of brazilian medicinal plant, pariparoba. Yakugaku Zasshi 2002, 122, 291-294. [CrossRef] [PubMed]

39. Smejkal, K.; Grycová, L.; Marek, R.; Lemière, F.; Jankovská, D.; Forejtníková, H.; Vanco, J.; Suchý, V. C-geranyl compounds from Paulownia tomentosa fruits. J. Nat. Prod. 2007, 70, 1244-1248. [CrossRef] [PubMed]

40. Han, X.H.; Hong, S.S.; Jin, Q.; Li, D.; Kim, H.-K.; Lee, J.; Kwon, S.H.; Lee, D.; Lee, C.-K.; Lee, M.K.; et al. Prenylated and benzylated flavonoids from the fruits of Cudrania tricuspidata. J. Nat. Prod. 2009, 72, 164-167. [CrossRef] [PubMed]

41. Wu, T.-S.; Hsu, M.-Y.; Kuo, P.-C.; Sreenivasulu, B.; Damu, A.G.; Su, C.-R.; Li, C.-Y.; Chang, H.-C. Constituents from the leaves of Phellodendron amurense var. wilsonii and their bioactivity. J. Nat. Prod. 2003, 66, 1207-1211. [CrossRef] [PubMed]

42. Teng, Y.; Li, X.; Yang, K.; Li, X.; Zhang, Z.; Wang, L.; Deng, Z.; Song, B.; Yan, Z.; Zhang, Y.; et al. Synthesis and antioxidant evaluation of desmethylxanthohumol analogs and their dimers. Eur. J. Med. Chem. 2017, 125, 335-345. [CrossRef] [PubMed]

43. Aponte, J.C.; Verástegui, M.; Málaga, E.; Zimic, M.; Quiliano, M.; Vaisberg, A.J.; Gilman, R.H.; Hammond, G.B. Synthesis, cytotoxicity, and anti-Trypanosoma cruzi activity of new chalcones. J. Med. Chem. 2008, 51, 6230-6234. [CrossRef] [PubMed]

44. Gong, J.; Huang, K.; Wang, F.; Yang, L.; Feng, Y.; Li, H.; Li, X.; Zeng, S.; Wu, X.; Stöckigt, J.; et al. Preparation of two sets of 5,6,7-trioxygenated dihydroflavonol derivatives as free radical scavengers and neuronal cell protectors to oxidative damage. Bioorg. Med. Chem. 2009, 17, 3414-3425. [CrossRef] [PubMed]

45. Marié, J.-C.; Xiong, Y.; Min, G.K.; Yeager, A.R.; Taniguchi, T.; Berova, N.; Schaus, S.E.; Porco, J.A. Enantioselective synthesis of 3,4-chromanediones via asymmetric rearrangement of 3-allyloxyflavones. J. Org. Chem. 2010, 75, 4584-4590. [CrossRef] [PubMed]

46. Woydowski, K.; Ziemer, B.; Liebscher, J. Ring transformation of glycidic amides with ortho-metalated phenols to enantiopure 3-hydroxychromanones. J. Org. Chem. 1999, 64, 3489-3491. [CrossRef] [PubMed]

47. Takahashi, H.; Kubota, Y.; Fang, L.; Li, S.; Onda, M. Heterocycles. XX. reactions of 2"-methoxymethoxychalcone epoxides under acidic conditions. Chem. Pharm. Bull. 1986, 34, 4597-4604. [CrossRef]

48. Momtazi, A.A.; Banach, M.; Pirro, M.; Katsiki, N.; Sahebkar, A. Regulation of PCSK9 by nutraceuticals. Pharmacol. Res. 2017, 120, 157-169. [CrossRef] [PubMed]

Sample Availability: Samples of the compounds are available from the authors. 